
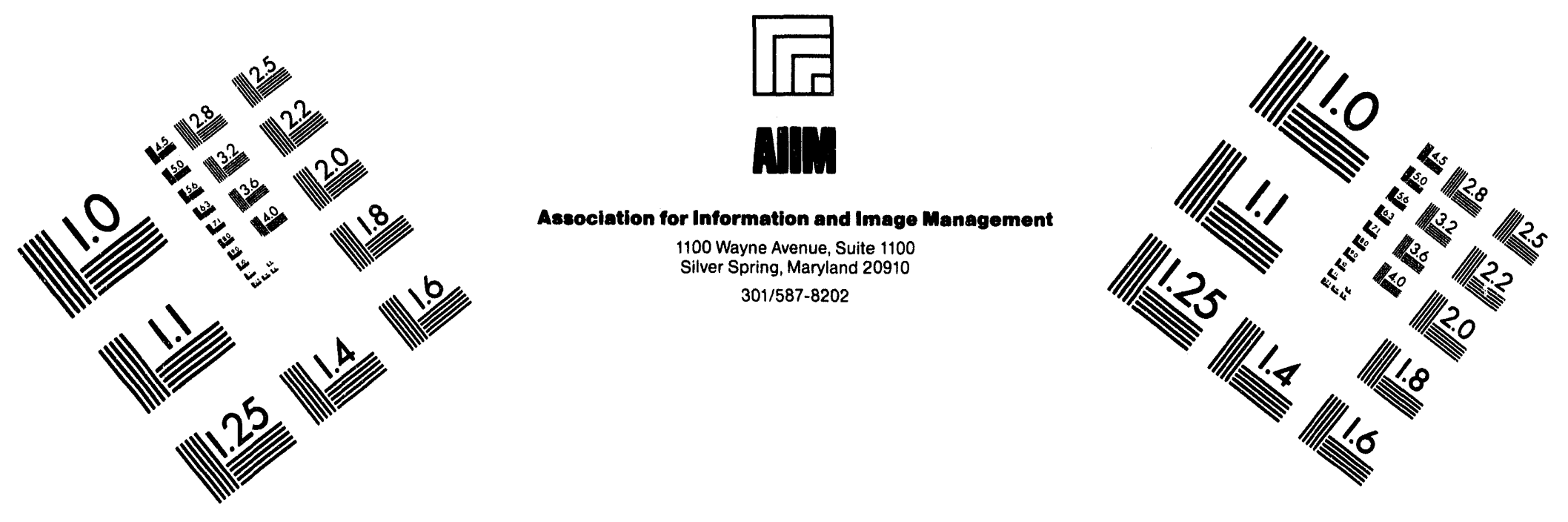

\title{
Centimeter
}

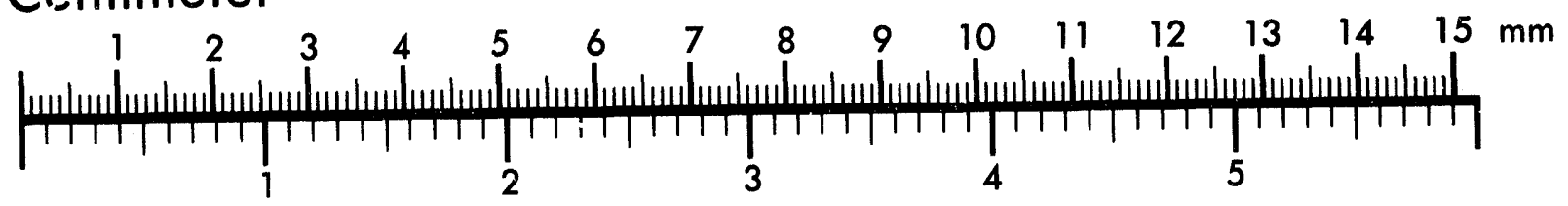
Inches
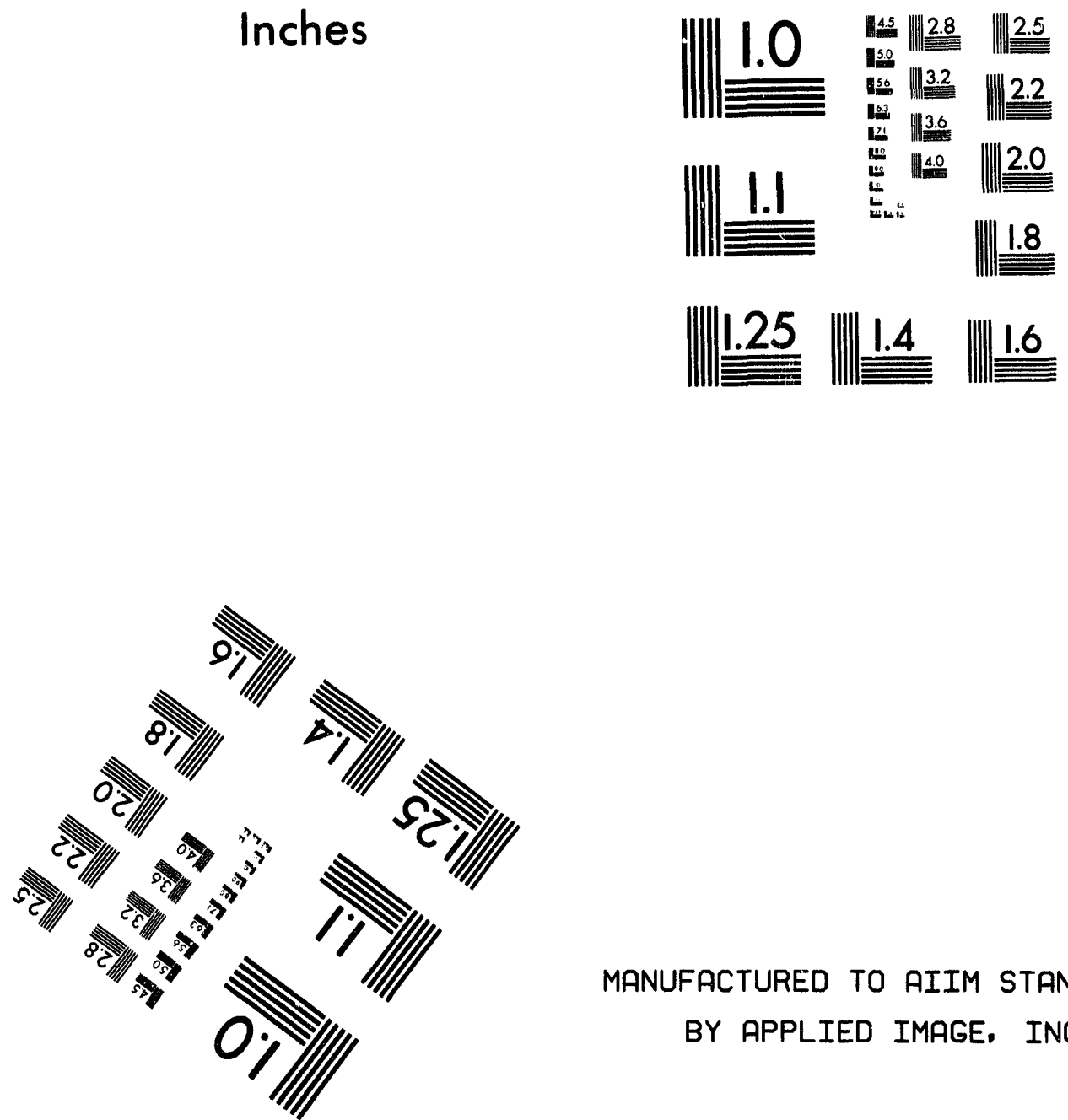

MANUFACTURED TO AIIM STANDARDS

BY APPLIED IMAGE, INC.

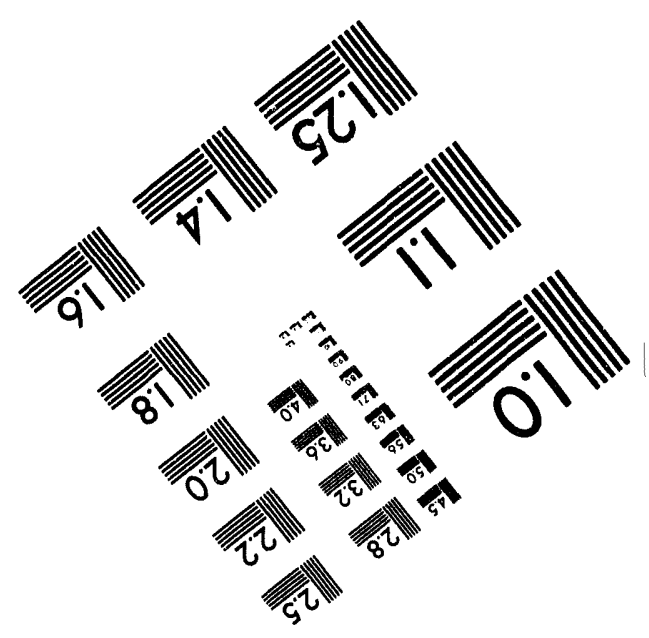



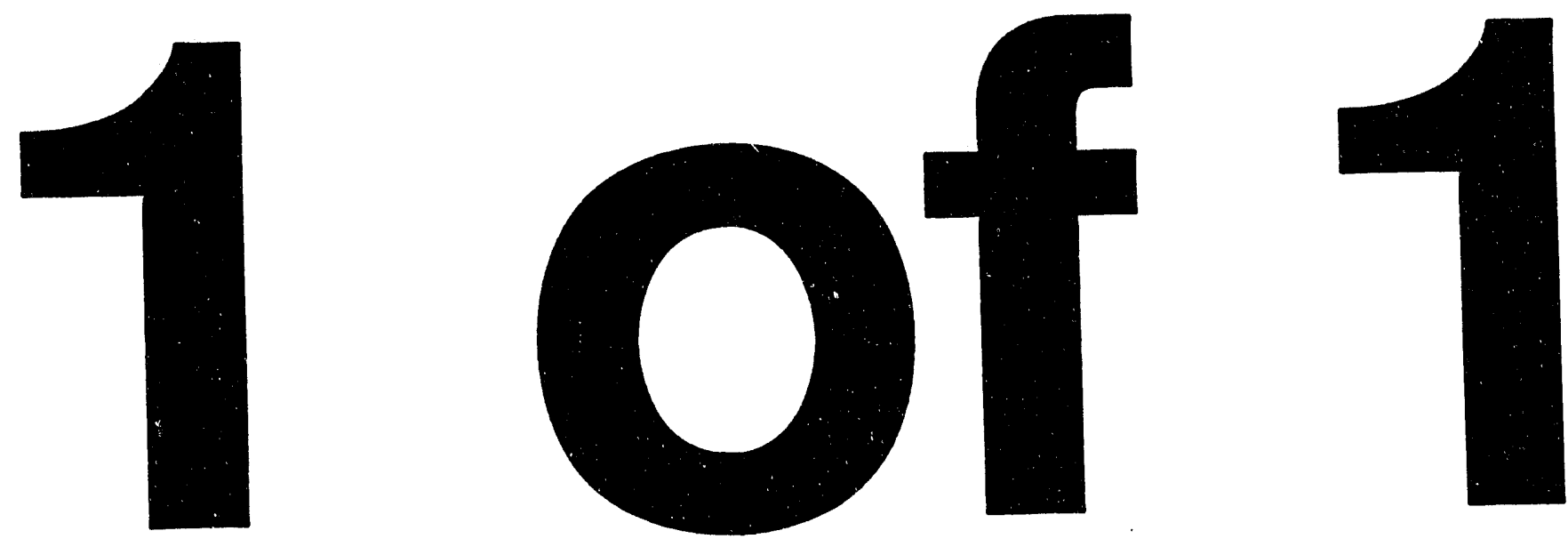


\section{SRTC CRITICALITY SAFETY TECHNICAL REVIEW: NUCLEAR CRITICALITY SAFETY EVALUATION 94-02 URANIUM SOLIDIFICATION FACILITY PENCIL TANK MODULE SPACING (U)}

by

Rathbun, $R$.

Westinghouse Savannah River Company

Savannah River Site

Alken, South Carolina 29808

This paper was prepared in connection with work done under the above contract number with the $U$. S

Department of Energy. By acceptance of this paper, the publisher and/or recipient acknowledges the U.S.

Government's right to retain a nonexclusive, royalty-free license in and to any copyright covering this paper, along with the right to reproduce and to authorize others to reproduce all or part of the copyrighted paper. 


\section{DISCLAIMER}

This report was prepared as an account of work spoasored by an ageacy of the United States Government. Neither the United States Government nor any agency thereof, nor any of their employees, makes any warranty, express or implied. or assumes any legal liability or responsibility for the accuracy, completeness, or usefulaess of any information. apparatus, product, or process disclosed, or represents that its use would not infriage privately owned rights. Refereace bereia to any specific commercial product, process. or service by trade name. trademark, manufacturer, or otherwise does not necessarily constitute or imply its endorsemeat, recommendation, or favoring by the United States Government or any agency thereof. The views and opinions of authors expressed herein do not aecessarily state or reflect those of the United States Government or any agency ihereof.

This report has been reproduced directly from the best available copy.

Available to DOE and DOE coatractors from the Office of Scientific and Technical Information. P. O. Box 62. Oak Ridge. TN 37831: prices available from (615) $576-8401$.

Available to the public from the National Techaical Lnformation Service. U. S. Deparmeat of Commerce, 5285 Port Royal Rd. Springfield. VA 22161 
SAVANNAH RIVER TECHNOLOGY CENTER

Applied Technology Section

Applied Physics Group

SRT-CMA-940017

SRTC CRITICALITY SAFETY TECHNICAL REVIEW:

NUCLEAR CRITICALITY SAFETY EVALUATION 94-02 URANIUM SOLIDIFICATION FACILITY PENCIL TANK MODULE SPACING (U)

April 26, 1994

Reviewer:

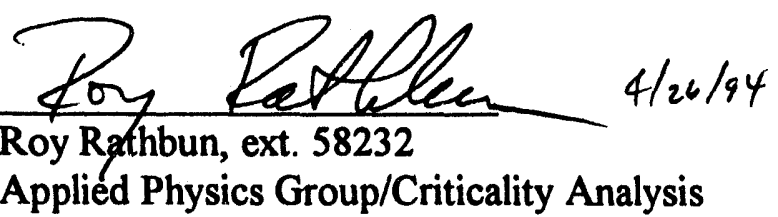

Approvals:

Task Leader, APG

Criticality Analysis and Training

Manager, Applied Physics Group (APG)

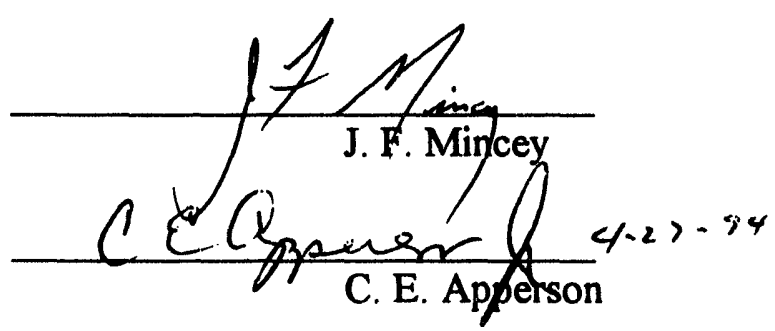

UNCLASSIFIED

DOES NOT CONTAIN UNCLASSIFIED CONTROLLED NUCLEAR INFORMATION

\begin{tabular}{ll} 
Reviewing & $\frac{C E(1)}{\text { C. E. Apperson, Manager APG }}$ \\
Date: & $4-27-84$ \\
\hline
\end{tabular}

Distribution:

M. J. Crouse

707-F

J. S. Bullington

707-F

M. R. Buckner,

$773-42 \mathrm{~A}$

R. L. Reed

$773-42 \mathrm{~A}$

J. F. Mincey

$773-22 \mathrm{~A}$

C. E. Apperson

$773-42 \mathrm{~A}$

T. A. Reilly

707-F

T. G. Williamson

$773-42 \mathrm{~A}$

J. F. Zino

773-22A

E. F. Trumble

$786-1 \mathrm{~A}$

Technical Information Mgmt 703-43A 
Review of NMP-NCS-94-0087, "Nuclear Criticality Safety Evaluation 94-02: Uranium Solidification Facility Pencil Tank Module Spacing (U), April 18, 1994," was requested of the SRTC Applied Physics Group. The NCSE is a criticality assessment to show that the USF process module spacing, as given in Non-Conformance Report SHM-0045, remains safe for operation.

The NCSE under review concludes that the module spacing as given in Non-Conformance Report SHM-0045 remains in a critically safe configuration for all normal and single credible abnormal conditions. After a thorough review of the NCSE, this reviewer agrees with that conclusion.

\section{SCOPE OF TECHNICAL REVIEW}

This technical review consisted of:
$\rightarrow$ an independent check of the methods and models employed,
$\Rightarrow$ inspection of NCSE author's microfiche output;
$\rightarrow$ verification of WSRC Nuclear Criticality Safety Manual(1) procedures.

DOCUMENTATION

Issuance of this memorandum transmits this technical review as critical data.

METHOD AND MODEL REVIEW

\section{Method:}

\section{Cross-Sections \& Computer Codes}

\section{HRXN/JSWL/KENO-V.a:}

Cross-section processing was performed with HRXN and JSWL. These are validated codes developed at SRS, and included as part of the JOSHUA-70 system(2). The 16Group Hansen-Roach cross-section data libraries were employed and processed with the HRXN code. The Hansen-Roach Library is an extensively employed database for criticality safety analysis. JSWL converts these cross-sections to be compatible with KENO-V.a, which is outside the JOSHUA system. The system keff is predicted with KENO-V.a, an SRS validated Monte Carlo criticality calculational code developed at Oak Ridge National Laboratory as part of the SCALE(3) package. The KENO-V.a code is widely used throughout the industry for performing criticality safety calculations. 


\section{Model:}

The sixteen material cross-section sets generated by the HRXN calculations were checked and verified.

The KENO-V.a model that contains the most detailed equipment room description was checked and verified.

\section{EVALUATION}

Data to perform this evaluation were derived from the NCSE under review, as well as from private communications with the author and the original SRTC reviewer (J. Mincey).

\section{NCSE CONTENT EVALUATION $\cos 6808$}

\section{Bias Applied, Subcritical Margin and K-safe:}

Bias: The bias applied is 0.0250 and is the most conservative value for U235-water mixture systems predicted with the HRXN/KENO criticality method(4).

Subcritical Margin: The subcritical margin applied for both normal and accident conditions is $0.05 \Delta \mathrm{k}$, which is the commonly used value for criticality evaluations. Since fissile material for this evaluation is always in solution, and therefore uniformly distributed by definition, no additional margin is imposed for non-uniform spatial distribution of fissile material.

K-safe: The K-safe used for the NCSE is $1.000-0.025$ (bias) -0.050 (margin) $=0.925$.

It should be noted that for the KENO calculations, 3 standard deviations $(\sigma)$ are always added to the nominal keff.

\section{Review of NCSE Conclusions:}

The NCSE under review is a criticality assessment to show that the USF process module spacing, as given in Non-Conformance Report SHM-0045, remains safe for operation. The NCSE concludes that the module spacing as given in the Non-Conformance Report maintains a critically safe configuration for all normal and single credible abnormal conditions. The following is an assessment of how that conclusion was reached.

The USF Process Module Room, the area that is the subject of non-conformance, basically contains 2 types of modules; evaporator modules ( 2 total) and feed or collection modules ( 5 total). The only difference modeled between the modules is that the evaporator modules (designated hereafter as EM) use 17 foot tall, 6" schedule 40 steel pipe and the 
SRT-CMA-940017

Page 4 of 6

feed or collection modules (designated hereafter as FCM) use 13.5 foot tall, 5 " schedule 40 steel pipe. After reviewing the drawings this is deemed appropriate. Drawings indicate about $15.5^{\prime}$ for EMs and about $13^{\prime}$ for FCMs.

As-built measurements between the modules were provided to the NCSE author by $P$. Pappas ( provided to this reviewer by author). The author used the smallest separation measured between any of the module units as the basis for his KENO model floor layout. Additional conservatism was added by using model spacing less than any measurement. Other conservatisms built into the KENO model were:

1. steel pipe walls were modeled at less than half thickness;

2. module tanks are spaced $2 "$ apart, whereas drawings indicate the least spacing to be 2'1";

3. the bottom of each pipe was modeled as only 12 " above the concrete floor, whereas drawings indicate more than 2 feet of spacing exists;

4. steel pipes, other than the tank pipes, were ignored; they would have added neutron poison;

5. optimally moderated solutions are always employed (more of a requirement than a conservatism).

\section{Normal Conditions}

Under normal conditions, the keff $(\mathrm{k}$ _average +3 sigma; which is the value which will always be quoted henceforth) is in the range of 0.85 to 0.86 , depending on the specific model. Normal conditions are defined as all EMs and FCMs full of solution, dry air and floor, and empty sumps.

\section{Accident Conditions}

This room is designed to process UNH solution in the EMs and FCMs. No movement of fissile material outside of the module piping is planned. Therefore the range of accidents envisioned would be activation of sprinklers and solution spillage. These were addressed by the author and described here.

\section{Sprinklers}

The room is equipped with sprinklers and thus a potential increase in air moisture would increase neutron reflection and thus increase reactivity. Results indicate that the air would have to contain about $8 \%$ water to exceed k-safe. Previous studies $(5)$ have shown that sprinklers add only about $0.01 \%$ water to the air, hence sprinkler activation will not violate criticality safety.

It should be noted that barriers are put in-place before operation to preclude worker reflection effects. This includes both the module tanks and the sumps below each module. 
2. Solution Spills

The entire floor would need to be covered with about $3 / 4$ " of solution before $k$-safe is violated. The floor liner retains water up to only a 19/32" depth before it overflows.

\section{Sump Spills}

Solution spills up to $2^{\prime \prime}$ depth in the sumps could occur before $k$-safe is violated. The maximum sump depth is $13 / 16^{\prime \prime}$. This conclusion holds for the 1 " $\times 1$ " sump trough being filled, and whether air, ordinary concrete or Oak Ridge concrete is under the sump.

\section{Combination of accidents}

One set of calculations was performed to determine the $k$-eff for a combination of effects. This combination includeds a 1" spill into all sumps (conservative), room air with $1 \%$ water (conservative) and a $0.5 \mathrm{~cm}$ water film on all module pipes (conservative, see ref. 6). The keff is below k-safe for this combination.

This reviewer agrees with all conclusions derived in the evaluations section for normal, as well as accident conditions.

\section{INDEPENDENT KENO-V.a CALCULATIONS $\cos \cos$}

Due to the extensive treatment by the NCSE author and the conservatism built into the accident scenarios, it was not felt that independent calculations were necessary. 


\section{SAFETY MANUAL FORMAT AND PROCEDURES}

The WSRC Nuclear Criticality Safety Manual spells out certain requirements that are to be included in a specifically formatted NCSE. This section reviews the compliance with that document.

\begin{tabular}{|l|l|}
\hline \multicolumn{1}{|c|}{ SECTION } & \multicolumn{1}{c|}{ REMARKS } \\
\hline 1.0 Introduction: & Included with appropriate contents \\
\hline 2.0 Description: & Included with appropriate contents \\
\hline 3.0 Requirements Documentation & Included with appropriate contents \\
\hline 4.0 Methodology & Included with appropriate contents \\
\hline 5.0 Discussion of Contingencies & Included with appropriate contents \\
\hline 6.0 Evaluation of Results & Included with appropriate contents \\
\hline $\begin{array}{l}\text { 7.0 Administratively Controlled } \\
\text { Limits and Requirements }\end{array}$ & Included with appropriate contents \\
\hline 8.0 Summary and Conclusions & Included with appropriate contents \\
\hline 9.0 References & Included with appropriate contents \\
\hline
\end{tabular}

REFERENCES

1. WSRC Nuclear Criticality Safety Manual (U), WSRC-IM-93-13, Rev.1, 7/1/93.

2. DPSTM-86-700-3; H. K. Clark, "JOSHUA Nuclear Criticality Safety Modules," March 1987.

3. NUREG/CR-0200;ORNL/NUREG/CSD-2/R1; "SCALE, A Modular Code System for Performing Standardized Computer Analyses for Licensing Evaluation," Oct., 1981.

4. H. K. Clark, "Subcritical Limits for U-235 Systems," Nuclear Science and Engineering, Vol. 81, 1982.

5. G. R. Handley, "Effect of Water Sprinklers on Array Criticality Safety Analyses," UCCND ANS Trans., pg 665-666 (1980).

6. Ross to Runnels, "Water Film Thickness Study (U)," WSRC Inter-Office Memo, NMPNCS-93-0043, October 29, 1993. 
1Q34

NRTSC QA Procedures

QA Program Procedures, Category 4
RAP $\|-14$, Rev. 0

Effective $8 / 1 / 91$

Page 8 of 8

Attachment $B^{R} A R$

Review Sheet Form

SR 24-K7

Task title Technical Review of NCSE $94-02$ Task number N/A

Item reviewed NMP-NCS- $94-0087$

Page $\frac{1}{1}$ of

(Attach additional pages as necessary; marked-up pages are acceptable.)

1. Areas reviewed (identify clearly each area reviewed).

See scope on page 2 fo 6

2. Approaches used to perform the review.

See scope on page 2 of 6

3. Questions, comments to be resolved.

None.

I agree with the technical content.

I disagree with the technical content.

I accept the conclusions and recommendations.

I do not accept the conclusions and recommendations for the following reasons:

Reviewer signature

Date 4122194

Refer to NRTSC procedure 11-14, Technical Review," for additional information. 

